\title{
Surprising decline of cardiovascular mortality in Switzerland: 1951-1976
}

\author{
E. GUBERAN \\ From the Occupational Health Service of the Canton of Geneva
}

SUMMARY In Switzerland the age-standardised death rate for 'all diseases of the circulatory system' decreased by $22 \%$ in males and by $43 \%$ in females between 1951 and 1976, which represented a third and nearly a half respectively of the decrease in all deaths. Mortality was reduced by $13 \%$ in males and by $40 \%$ in females for non-rheumatic heart disease and hypertension, and by $36 \%$ and $47 \%$ respectively for cerebrovascular disease. These reductions were on the whole greater than those observed in the 13 other developed countries studied. From 1951 to 1976 consumption of animal fats per caput increased by $20 \%$ in Switzerland, in spite of a $46 \%$ reduction in milk intake. Throughout the same period, smoking increased among women while it remained steady or possibly declined in men. During the last decade a threefold rise in the sales of antihypertensive drugs was observed. Oral contraceptives seem to have been widely used by Swiss women since the $1960 \mathrm{~s}$. There were also increases in the proportion of women in professional occupations, and in urbanisation. The advent of the economic recession was associated with a sudden rise in mortality from non-rheumatic heart disease and hypertension in 1974-76.

Attention was recently drawn to the decline of more than $20 \%$ in coronary mortality and cerebrovascular mortality in the United States of America from 1963 to 1975 (Walker, 1977). This fall was attributed mainly to the associated reduction in consumption of animal fats and tobacco products. This paper deals with trends in major cardiovascular diseases during the third quarter of this century in Switzerland. Some data have been compared with those of 13 developed countries.

\section{Methods}

The numbers of deaths by sex and five-year age groups are published each year by the Federal Bureau of Statistics (1955-77) and since 1951 according to the A-list of the International Classification of Diseases (World Health Organisation, 1948). Death rates per 100000 population were calculated by using as denominator the mean of the estimated population as at 1 January of the year considered and of the following year (Federal Bureau of Statistics, 1955-77).

From 1951 to 1976 life expectancy rose in Switzerland from 66.4 to 71.7 years in males and from 71.0 to 78.3 years in females; births per 1000 population grew to a peak in 1964 at 19.2 and then steadily fell to 11.7 in 1976 (Federal Bureau of
Statistics, 1955-77). Both factors produced a marked increase in the percentage of the population aged 70 and over $(5.0 \%$ to $6.6 \%$ in males and $6.6 \%$ to $10.1 \%$ in females). Since most cardiovascular deaths occur in this group (67\% of male deaths and $86 \%$ of female deaths in 1976) the trends in crude death rates have little meaning. Direct age-standardised death rates per 100000 population were then calculated by using as standard the total population of the census of 1 December 1950.

According to the suggestion of Clayton et al. (1977) we combined together as 'non-rheumatic heart disease and hypertension' the three subcategories of the 6th and 7th revisions of the International Classification of Diseases (World Health Organisation, 1948; 1957): arteriosclerotic and degenerative heart diseases (A81); other diseases of the heart (A82); hypertension with heart disease (A83); and hypertension without mention of heart (A84)-as well as the corresponding subcategories of the 8th revision of the International Classification of Diseases (World Health Organisation, 1967): ischaemic heart disease (A83); other forms of heart disease (A84); and hypertensive disease (A82). The main reasons for this grouping, discussed elsewhere (Beral, 1976; Clayton et al., 1977) were to overcome the discontinuity introduced by the $I C D$ 8th revision in coronary mortality and the 114 
bias due to a possible change in diagnostic fashion within and between countries. Death rates for most of the industrial countries which had introduced the $I C D$ 6th revision in 1951 or before were drawn from publications by the World Health Organisation and the United Nations (World Health Organisation, 1954-64; 1965-77; United Nations Association, $1956 ; 1965)$.

\section{Results}

From 1951 to 1976, the age-standardised death rate from 'all diseases of the circulatory system' decreased by $22 \%$ in males and by $43 \%$ in females. These reductions accounted for a third of the total reduction in deaths of males and for nearly half of the total reduction in deaths of females.

The trend in death rates for the four categories of cardiovascular diseases is shown in Fig. 1 and Table 1. For non-rheumatic heart disease and hypertension a steady decline of $40 \%$ occurred in females; the male death rate, however, fluctuated until 1963, then decreased until $1973(-24 \%)$ and finally rose sharply between 1973 and $1976(+12 \%)$, which resulted in an overall decline from $1951-76$ of $13 \%$. Therefore, the male to female ratio of age-standardised death rates rose from 1.3 in 1951 to 1.9 in 1976.

For the three other categories a much smaller difference in downward trends and in levels of death rates was observed between the sexes. The decline of cerebrovascular mortality was constant for both sexes, although a little greater in females than in males. Similarly, the death rate for rheumatic heart disease dropped in males and females during the 1950 s and then stabilised itself at a very low level. For 'all other circulatory diseases' a downward trend in

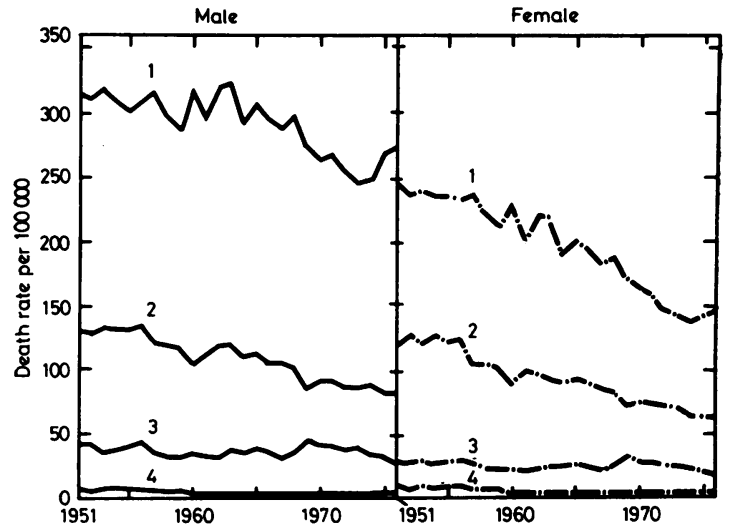

Fig. 1 Age-standardised death rates for non-rheumatic heart disease and hypertension (1), cerebrovascular disease (2), all other circulatory diseases (3), and rheumatic heart disease (4), Switzerland, 1951-1976.

death rates may have been obscured by some transfer of diagnosis from the other categories until 1968. But since the introduction of the ICD 8th revision, a pronounced decline, similar in both sexes, was observed until 1976.

The trend in age-specific death rates from non-rheumatic heart disease and hypertension is shown in Fig. 2. In females, the decrease was of 50\% to $60 \%$ except in the two oldest age groups $(-38 \%$ and $-4 \%)$. In males, however, the decline was much more moderate (between $-6 \%$ and $-16 \%$ ) except in the youngest age group $(-40 \%)$.

Ischaemic heart disease was introduced as a definite entity in the ICD 8th revision used in Switzerland since 1969. Standardised death rates per

Table 1 Age-standardised $\dagger$ death rates per 100000 population for diseases of the circulatory system in males and females: Switzerland, 1951 and 1976

\begin{tabular}{|c|c|c|c|c|c|c|c|}
\hline $\begin{array}{l}I C D \\
\text { revision } \ddagger\end{array}$ & $\begin{array}{l}\text { A-list } \\
\text { number }\end{array}$ & Disease & Sex & 1951 & 1976 & $\begin{array}{l}1951-1976 \\
\text { \% change }\end{array}$ & $\begin{array}{l}\text { \% of total } \\
\text { reduction in deaths }\end{array}$ \\
\hline $\begin{array}{l}(6 / 7) \\
(8)\end{array}$ & $\begin{array}{l}\text { A70, A79-86 } \\
\text { A80-88 }\end{array}$ & $\begin{array}{l}\text { All diseases of the } \\
\text { circulatory system }\end{array}$ & $\begin{array}{l}\mathbf{M} \\
\mathbf{F}\end{array}$ & $\begin{array}{l}500 \cdot 7 \\
411 \cdot 2\end{array}$ & $\begin{array}{l}390 \cdot 8 \\
234.9\end{array}$ & $\begin{array}{l}-21 \cdot 9 \\
-42 \cdot 9\end{array}$ & $\begin{array}{l}34 \cdot 2 \\
45 \cdot 1\end{array}$ \\
\hline $\begin{array}{l}(6 / 7) \\
(8)\end{array}$ & $\begin{array}{l}\text { A81-84 } \\
\mathbf{A 8 2}-84\end{array}$ & $\begin{array}{l}\text { Non-rheumatic heart } \\
\text { disease and hypertension }\end{array}$ & $\begin{array}{l}\mathbf{M} \\
\mathbf{F}\end{array}$ & $\begin{array}{l}317 \cdot 0 \\
248 \cdot 2\end{array}$ & $\begin{array}{l}275 \cdot 7 \\
148 \cdot 2\end{array}$ & $\begin{array}{l}-13 \cdot 0 \\
-40 \cdot 3\end{array}$ & $\begin{array}{l}12 \cdot 8 \\
25 \cdot 6\end{array}$ \\
\hline $\begin{array}{l}(6 / 7) \\
(8)\end{array}$ & $\begin{array}{l}\text { A70 } \\
\mathbf{A 8 5}\end{array}$ & $\begin{array}{l}\text { Cerebrovascular } \\
\text { disease }\end{array}$ & $\begin{array}{l}\mathbf{M} \\
\mathbf{F}\end{array}$ & $\begin{array}{l}131 \cdot 4 \\
120 \cdot 8\end{array}$ & $\begin{array}{l}83 \cdot 8 \\
64 \cdot 5\end{array}$ & $\begin{array}{l}-36 \cdot 2 \\
-46 \cdot 6\end{array}$ & $\begin{array}{l}14 \cdot 8 \\
14 \cdot 4\end{array}$ \\
\hline $\begin{array}{l}(6 / 7) \\
(8)\end{array}$ & $\begin{array}{l}\text { A79, } \mathbf{A 8 0} \\
\mathbf{A 8 0}, \mathbf{A 8 1}\end{array}$ & $\begin{array}{l}\text { Rheumatic } \\
\text { heart disease }\end{array}$ & $\begin{array}{l}\mathbf{M} \\
\mathbf{F}\end{array}$ & $\begin{array}{r}9 \cdot 1 \\
11 \cdot 8\end{array}$ & $\begin{array}{l}2 \cdot 9 \\
2 \cdot 6\end{array}$ & $\begin{array}{l}-68 \cdot 1 \\
-78 \cdot 0\end{array}$ & $\begin{array}{l}1 \cdot 9 \\
2 \cdot 4\end{array}$ \\
\hline $\begin{array}{l}(6 / 7) \\
(8)\end{array}$ & $\begin{array}{l}\text { A85, A86 } \\
\text { A86-88 }\end{array}$ & $\begin{array}{l}\text { All other } \\
\text { circulatory diseases }\end{array}$ & $\begin{array}{l}\mathbf{M} \\
\mathbf{F}\end{array}$ & $\begin{array}{l}43 \cdot 3 \\
30 \cdot 4\end{array}$ & $\begin{array}{l}28 \cdot 5 \\
19 \cdot 6\end{array}$ & $\begin{array}{l}-34 \cdot 2 \\
-35 \cdot 5\end{array}$ & $\begin{array}{l}4 \cdot 6 \\
2 \cdot 8\end{array}$ \\
\hline
\end{tabular}

† Standard population: total population of Switzerland (1950 census).

¥ 6th revision (World Health Organisation, 1948).

7th revision (World Health Organisation, 1957).

8th revision (World Health Organisation, 1967). 


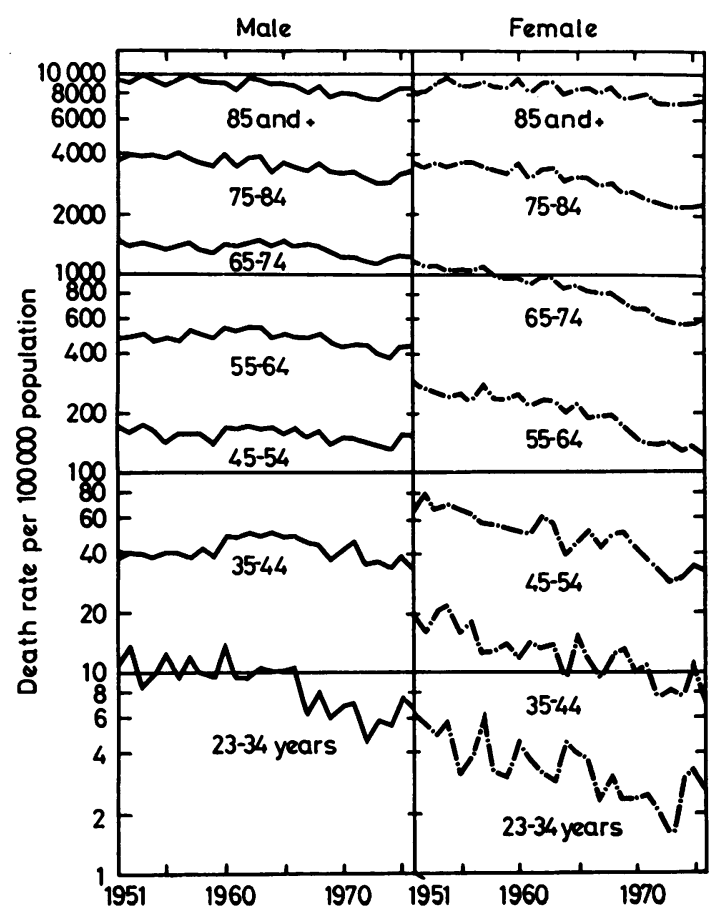

Fig. 2 Age-specific death rates for non-rheumatic heart disease and hypertension, Switzerland, 1951-1976

10-year death rates have been standardised from two 5-year crude death rates according to the total population of Switzerland (1950 census).

100000 population ranged between 134 and 151 in males and between 53 and 56 in females for the years 1969 to 1976 . It is very likely that a threefold mortality in males occurred also before 1969 and was the major contributory factor of the difference between the sexes, both in trends and in levels of death rates for the whole category of non-rheumatic heart disease and hypertension.

\section{INTERNATIONAL COMPARISONS}

Age-standardised death rates for the two main categories of cardiovascular diseases in 14 countries are given in Table 2 for the years 1951, 1963, and 1974.

Considering only the 1951-1974 trend in death rates, for both groups of diseases and for both sexes, the sharpest decline was observed in Switzerland, Canada, the United States of America, England and Wales, and France.

For non-rheumatic heart disease and hypertension the trend in death rates in all countries was much better for females than for males (Fig. 3). For the former, the reduction was of $20 \%$ to $40 \%$ in most countries, with only Japan and Finland showing a slight increase; for the latter, an increase was recorded in six countries. In most of the countries where the male death rate decreased, the fall occurred between 1963 and 1974. In the earlier period, from 1951 to 1963 , it either remained stationary or rose. In females, however, there was usually a steady decline in the death rate throughout the whole period 1951-74. In 1974 the male to female ratio of standardised death rates ranged from $1 \cdot 8$ to $2 \cdot 1$ in all countries except Italy $(1 \cdot 5)$ and Japan $(1 \cdot 3)$

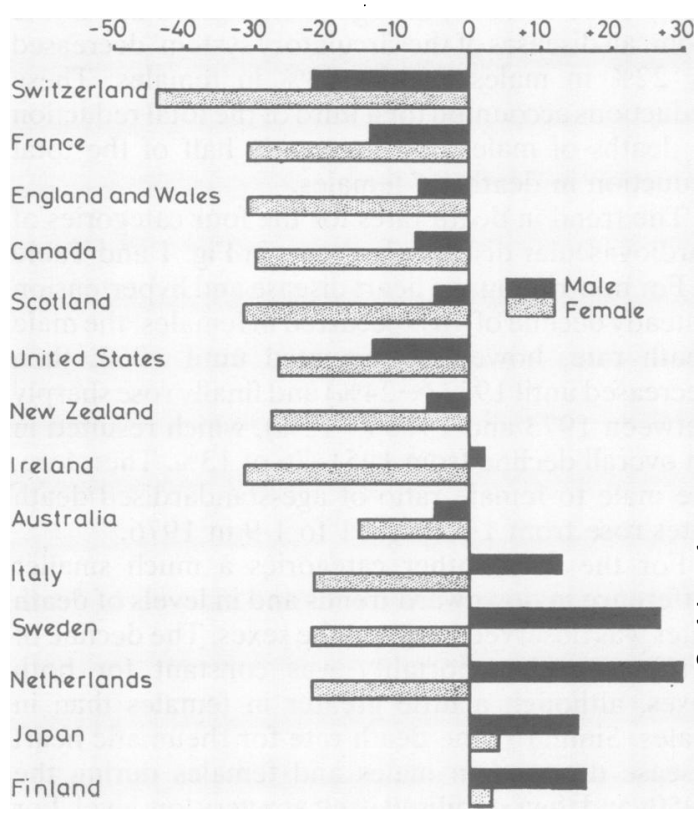

Fig. 3 Percentage change 1951-1974 in age-standardised death rates for non-rheumatic heart disease and hypertension in 14 countries.

For cerebrovascular disease, results concerning the trend in death rates were better in females than in males in all countries, but the difference between the sexes was smaller than for the first category. Also, the male to female ratio of standardised death rates for 1974 ranged only from 0.97 (Ireland) to 1.45 (Japan). On the whole, the decrease in mortality rates was more pronounced for cerebrovascular disease than for non-rheumatic heart disease and hypertension; the difference was slight in females and marked in males.

\section{Discussion}

In view of the use of broad categories of cardiovascular diseases, changing diagnostic habits are unlikely to have had a significant influence on the 
Table 2 Age-standardised $\dagger$ death rates per 100000 population for non-rheumatic heart disease and hypertension and for cerebrovascular disease in males and females: 14 countries, 1951, 1963, and 1974

\begin{tabular}{|c|c|c|c|c|c|c|c|c|c|}
\hline \multirow[b]{2}{*}{ Country } & \multirow[b]{2}{*}{ Sex } & \multicolumn{4}{|c|}{ Non-rheumatic heart disease and hypertension } & \multicolumn{4}{|c|}{ Cerebrovascular disease } \\
\hline & & 1951 & 1963 & 1974 & $\begin{array}{l}1951-1974 \\
\text { \% change }\end{array}$ & 1951 & 1963 & 1974 & $\begin{array}{l}\text { 1951-1974 } \\
\text { \% change }\end{array}$ \\
\hline Switzerland & $\begin{array}{l}\mathbf{M} \\
\mathbf{F}\end{array}$ & $\begin{array}{l}317 \cdot 0 \\
248 \cdot 2\end{array}$ & $\begin{array}{l}325 \cdot 2 \\
221 \cdot 6\end{array}$ & $\begin{array}{l}249 \cdot 1 \\
140 \cdot 0\end{array}$ & $\begin{array}{l}-21 \cdot 4 \\
-43 \cdot 6\end{array}$ & $\begin{array}{l}131 \cdot 4 \\
120 \cdot 8\end{array}$ & $\begin{array}{r}120.6 \\
95.0\end{array}$ & $\begin{array}{l}88 \cdot 0 \\
66 \cdot 1\end{array}$ & $\begin{array}{l}-33 \cdot 0 \\
-45 \cdot 3\end{array}$ \\
\hline Canada & $\begin{array}{l}\mathbf{M} \\
\mathbf{F}\end{array}$ & $\begin{array}{l}411.0 \\
273.4\end{array}$ & $\begin{array}{l}412.9 \\
226.4\end{array}$ & $\begin{array}{l}381.9 \\
190.7\end{array}$ & $\begin{array}{l}-7 \cdot 1 \\
-30 \cdot 2\end{array}$ & $\begin{array}{l}108 \cdot 0 \\
119.9\end{array}$ & $\begin{array}{l}92.9 \\
88.9\end{array}$ & $\begin{array}{l}85 \cdot 7 \\
70 \cdot 1\end{array}$ & $\begin{array}{l}-20 \cdot 6 \\
-41 \cdot 5\end{array}$ \\
\hline United States & $\begin{array}{l}\mathbf{M} \\
\mathbf{F}\end{array}$ & $\begin{array}{l}497 \cdot 3 \\
307 \cdot 8\end{array}$ & $\begin{array}{l}493.4 \\
265.0\end{array}$ & $\begin{array}{l}432 \cdot 2 \\
225 \cdot 2\end{array}$ & $\begin{array}{l}-13 \cdot 1 \\
-26 \cdot 8\end{array}$ & $\begin{array}{l}125 \cdot 0 \\
118 \cdot 0\end{array}$ & $\begin{array}{r}110.4 \\
95.0\end{array}$ & $\begin{array}{l}93 \cdot 3 \\
80 \cdot 0\end{array}$ & $\begin{array}{l}-25 \cdot 4 \\
-32 \cdot 2\end{array}$ \\
\hline England and Wales & $\begin{array}{l}\mathbf{M} \\
\mathbf{F}\end{array}$ & $\begin{array}{l}419 \cdot 8 \\
279.0\end{array}$ & $\begin{array}{l}411 \cdot 5 \\
216 \cdot 7\end{array}$ & $\begin{array}{l}390 \cdot 1 \\
191 \cdot 5\end{array}$ & $\begin{array}{l}-7.1 \\
-31.4\end{array}$ & $\begin{array}{l}141 \cdot 2 \\
133 \cdot 3\end{array}$ & $\begin{array}{l}138 \cdot 0 \\
119 \cdot 7\end{array}$ & $\begin{array}{l}114 \cdot 3 \\
104 \cdot 6\end{array}$ & $\begin{array}{l}-19 \cdot 1 \\
-21 \cdot 5\end{array}$ \\
\hline France & $\begin{array}{l}\mathbf{M} \\
\mathbf{F}\end{array}$ & $\begin{array}{l}229 \cdot 3 \\
159 \cdot 0\end{array}$ & $\begin{array}{l}216 \cdot 6 \\
125 \cdot 1\end{array}$ & $\begin{array}{l}198 \cdot 2 \\
109 \cdot 4\end{array}$ & $\begin{array}{l}-13 \cdot 6 \\
-31 \cdot 2\end{array}$ & $\begin{array}{l}135 \cdot 7 \\
105 \cdot 1\end{array}$ & $\begin{array}{r}121 \cdot 2 \\
85 \cdot 2\end{array}$ & $\begin{array}{r}117 \cdot 9 \\
84 \cdot 1\end{array}$ & $\begin{array}{l}-13 \cdot 1 \\
-20 \cdot 0\end{array}$ \\
\hline Sweden & $\begin{array}{l}\mathbf{M} \\
\mathbf{F}\end{array}$ & $\begin{array}{l}267 \cdot 5 \\
221 \cdot 9\end{array}$ & $\begin{array}{l}320 \cdot 7 \\
201 \cdot 0\end{array}$ & $\begin{array}{l}340 \cdot 5 \\
173 \cdot 8\end{array}$ & $\begin{array}{l}+27 \cdot 3 \\
-21 \cdot 7\end{array}$ & $\begin{array}{l}119.5 \\
131.9\end{array}$ & $\begin{array}{l}95 \cdot 2 \\
91 \cdot 1\end{array}$ & $\begin{array}{l}78.9 \\
68.0\end{array}$ & $\begin{array}{l}-34 \cdot 0 \\
-48 \cdot 4\end{array}$ \\
\hline Scotland & $\begin{array}{l}\mathbf{M} \\
\mathbf{F}\end{array}$ & $\begin{array}{l}481 \cdot 2 \\
339 \cdot 3\end{array}$ & $\begin{array}{l}488 \cdot 0 \\
269 \cdot 4\end{array}$ & $\begin{array}{l}458 \cdot 2 \\
231 \cdot 9\end{array}$ & $\begin{array}{l}-4 \cdot 8 \\
-31.7\end{array}$ & $\begin{array}{l}172.6 \\
172.9\end{array}$ & $\begin{array}{l}174.4 \\
153.2\end{array}$ & $\begin{array}{l}156 \cdot 1 \\
139 \cdot 1\end{array}$ & $\begin{array}{r}-9.6 \\
-19.5\end{array}$ \\
\hline Italy & $\begin{array}{l}\mathbf{M} \\
\mathbf{F}\end{array}$ & $\begin{array}{l}246 \cdot 1 \\
237 \cdot 1\end{array}$ & $\begin{array}{l}298 \cdot 0 \\
224 \cdot 3\end{array}$ & $\begin{array}{l}278.6 \\
186.4\end{array}$ & $\begin{array}{l}+13.2 \\
-21.4\end{array}$ & $\begin{array}{l}163.8 \\
135.6\end{array}$ & $\begin{array}{l}146 \cdot 5 \\
111 \cdot 1\end{array}$ & $\begin{array}{r}122 \cdot 3 \\
96 \cdot 2\end{array}$ & $\begin{array}{l}-25 \cdot 3 \\
-29 \cdot 1\end{array}$ \\
\hline Finland & $\begin{array}{l}\mathbf{M} \\
\mathbf{F}\end{array}$ & $\begin{array}{l}418 \cdot 7 \\
226 \cdot 2\end{array}$ & $\begin{array}{l}511 \cdot 1 \\
289 \cdot 7\end{array}$ & $\begin{array}{l}487.6 \\
232.8\end{array}$ & $\begin{array}{r}+16.5 \\
+2.9\end{array}$ & $\begin{array}{l}152 \cdot 0 \\
182 \cdot 1\end{array}$ & $\begin{array}{l}159.6 \\
150.6\end{array}$ & $\begin{array}{l}120 \cdot 9 \\
100 \cdot 3\end{array}$ & $\begin{array}{l}-20.5 \\
-44.9\end{array}$ \\
\hline Netherlands & $\begin{array}{l}\mathbf{M} \\
\mathbf{F}\end{array}$ & $\begin{array}{l}220 \cdot 4 \\
187 \cdot 6\end{array}$ & $\begin{array}{l}284 \cdot 2 \\
175 \cdot 3\end{array}$ & $\begin{array}{l}287 \cdot 0 \\
147 \cdot 1\end{array}$ & $\begin{array}{l}+30.2 \\
-21.6\end{array}$ & $\begin{array}{r}95.3 \\
111.0\end{array}$ & $\begin{array}{l}94.3 \\
90.7\end{array}$ & $\begin{array}{l}83 \cdot 5 \\
74 \cdot 2\end{array}$ & $\begin{array}{l}-12 \cdot 4 \\
-33 \cdot 2\end{array}$ \\
\hline New Zealand & $\begin{array}{l}\mathbf{M} \\
\mathbf{F}\end{array}$ & $\begin{array}{l}427 \cdot 9 \\
284 \cdot 0\end{array}$ & $\begin{array}{l}437 \cdot 3 \\
228 \cdot 1\end{array}$ & $\begin{array}{l}401 \cdot 6 \\
206 \cdot 2\end{array}$ & $\begin{array}{r}-6.1 \\
-27.4\end{array}$ & $\begin{array}{r}98.6 \\
129.7\end{array}$ & $\begin{array}{l}111 \cdot 1 \\
111 \cdot 0\end{array}$ & $\begin{array}{l}120.4 \\
123.4\end{array}$ & $\begin{array}{l}+22.1 \\
-4.9\end{array}$ \\
\hline Ireland & $\begin{array}{l}\mathbf{M} \\
\mathbf{F}\end{array}$ & $\begin{array}{l}404 \cdot 9 \\
332 \cdot 0\end{array}$ & $\begin{array}{l}412 \cdot 5 \\
279.4\end{array}$ & $\begin{array}{l}411 \cdot 9 \\
228.6\end{array}$ & $\begin{array}{l}+1 \cdot 7 \\
-31 \cdot 1\end{array}$ & $\begin{array}{r}87 \cdot 9 \\
105 \cdot 6\end{array}$ & $\begin{array}{l}122.4 \\
128.4\end{array}$ & $\begin{array}{l}131 \cdot 6 \\
136 \cdot 1\end{array}$ & $\begin{array}{l}+49.7 \\
+28.9\end{array}$ \\
\hline Australia & $\begin{array}{l}\mathbf{M} \\
\mathbf{F}\end{array}$ & $\begin{array}{l}478 \cdot 2 \\
281 \cdot 4\end{array}$ & $\begin{array}{l}475 \cdot 5 \\
244 \cdot 3\end{array}$ & $\begin{array}{l}454 \cdot 9 \\
239 \cdot 2\end{array}$ & $\begin{array}{l}-4.9 \\
-15.0\end{array}$ & $\begin{array}{l}127.9 \\
147.9\end{array}$ & $\begin{array}{l}124 \cdot 9 \\
120 \cdot 2\end{array}$ & $\begin{array}{l}134 \cdot 3 \\
128 \cdot 6\end{array}$ & $\begin{array}{l}+5 \cdot 0 \\
-13 \cdot 0\end{array}$ \\
\hline Japan & $\begin{array}{l}\mathbf{M} \\
\mathbf{F}\end{array}$ & $\begin{array}{l}127.9 \\
106.6\end{array}$ & $\begin{array}{l}150 \cdot 8 \\
105 \cdot 1\end{array}$ & $\begin{array}{l}147 \cdot 4 \\
110 \cdot 4\end{array}$ & $\begin{array}{r}+15 \cdot 2 \\
+3.6\end{array}$ & $\begin{array}{l}255 \cdot 1 \\
206 \cdot 5\end{array}$ & $\begin{array}{l}316 \cdot 6 \\
214 \cdot 2\end{array}$ & $\begin{array}{l}241 \cdot 2 \\
166 \cdot 2\end{array}$ & $\begin{array}{r}-5.4 \\
-19.5\end{array}$ \\
\hline
\end{tabular}

TStandard population: total population of Switzerland (1950 census).

Sources:

Switzerland: see Methods section in text.

Other countries: Number of deathe and population estimate or census for the year 1951: World Health Organisation (1954-64); United Nations Association (1956; 1965).

Death rates for the years 1963 and 1974: World Health Organisation (1965-77).

Except for Ireland, 1963: number of deaths: World Health Organisation (1965-77) and 1961 population census: United Nations

Association (1956; 1965).

trends in death rates. Also, increased immigration into Switzerland, where the foreign population rose from $6.1 \%$ of the total in 1950 to $17 \cdot 2 \%$ in 1970 (Federal Bureau of Statistics, 1951-77), presumably had only a small effect on the trends observed, even if it is assumed that immigrants had cardiovascular death rates similar to those observed in their country of origin. More than half of the immigrants of both sexes came from Italy, where mortality from cardiovascular diseases was on the whole similar to that observed in Switzerland, or a little higher in recent years (World Health Organisation, 1954-64; 1965-77) (Table 2). Of the remainder of the foreign population, about $15 \%$ came from Germany and Austria and a similar proportion from France and Spain. The higher cardiovascular mortality in the former group must have balanced the lower one in the latter group (World Health Organisation, 1954-64; 1965-77). No epidemiological survey has dealt with trends in major cardiovascular risk factors in Switzerland during the last two decades. Nevertheless, some data on these factors can be drawn from various other sources and will be examined below.

There are no data on trends in the prevalence of diabetes mellitus, of elevated serum cholesterol, or of 
obesity, but a reliable estimate of food consumption based on home production, plus imports, less exports, is available (Secrétariat des Paysans Suisses, 1951-77). As shown in Fig. 4, average intake of

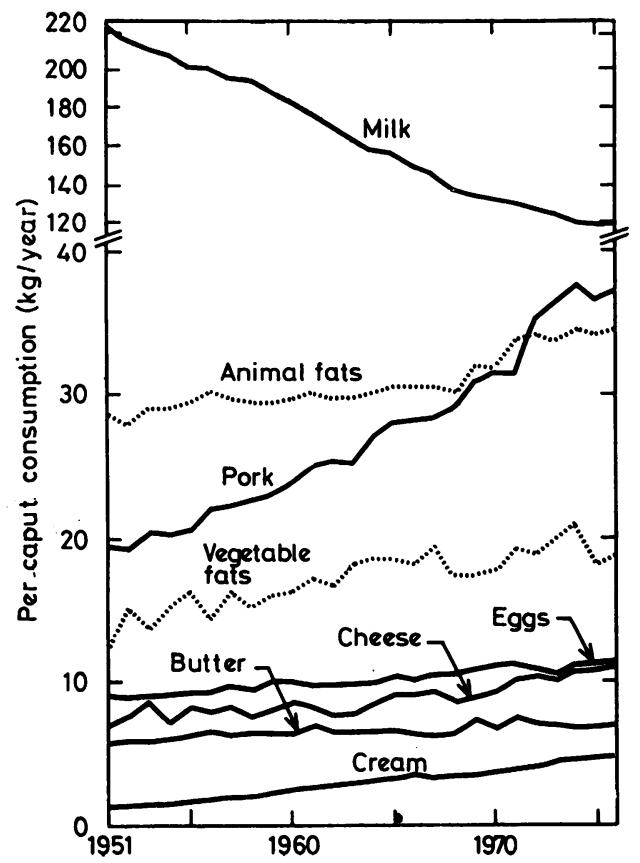

Fig. 4 Average per caput consumption of various foods and of animal and vegetable fats, Switzerland, 1951-1976

Source: Secretariat des Paysans Suisses (1951-1977). Since 1957 the calculations were made according to the recommendations of the United Nations Food and Agriculture Organisation. A small correction was introduced for the 1951-1956 data to take into account the slightly different methods of calculation.

animal fats per caput increased by $20 \%$ between 1951 and 1976 . The $46 \%$ fall in milk consumption was balanced by the increasing intake of pork, milk products, and eggs. Thus, contrary to the data obtained for the United States of America (Walker, 1977), the observed trends in cardiovascular mortality are negatively associated with the change in consumption of animal fats and only positively related to milk intake. This latter relationship is in agreement with the surprising association found by Segall in 43 countries between milk consumption and coronary mortality (Segall, 1977).

The average daily calorie intake per caput decreased from 3237 in 1957 to 3046 in 1976 (Secrétariat des Paysans Suisses, 1951-77). This trend is probably related to a reduction in physical activity, mainly among men, which results both from the advance of mechanisation in industry and agriculture and from the increased use of the motor car. Conversely, men probably took more exercise during the last decade, perhaps in response to the advice of medical men. Although we have no precise data, we notice an increasing awareness in men of the need to practise sport, mostly in the form of jogging, cross-country skiing, and cycling. Women, on the contrary, seem to be less affected by this enthusiasm for sport.

The annual sales of cigarettes per population aged 15 years and over rose dramatically from 1580 in 1951 to 3370 in 1973 (Lee, 1975). It should be noted, however, that this rise takes into account the ever increasing sales (estimated in recent years at one third of the total sales in the country) to residents in adjacent countries, tourists, and seasonal workers. Data from the only study of smoking habits based on a representative sample of the population (Abelin $\overrightarrow{0}$ and Wüthrich, 1976) show comparatively small differences in males between the age groups, except for the youngest age group (15-24) where the highest proportion of those who never smoked $(55 \%)$ was observed. On the contrary, young women smoked much more than older ones and the proportion of those who never smoked was higher in the oldest age group (76\%) than in the youngest (39\%). Therefore $\vec{A}$ as in other countries of Western Europe (Todक्ष 을 1975; Le Meitour-Kaplan, 1975), it is likely that smoking increased during the last two decades among $c$ women and remained unchanged or decrease 8 slightly among men.

The first antihypertensive drugs (hydralazine ante reserpine) were introduced in 1953 , followed by the thiazide diuretics in 1959 and other antihypertensive drugs in the 1960s. Data on the sales of these drugs show a steady rise from about 6 million Swiss francs in 1965 to 18.4 million in 1975 (Escher, 1977). Because of the lack of epidemiological data, we do not know if this large consumption of antihypertensive pills determined a significant reduction in the prevalence and/or fatality rates of hypertension.

The rise in the sales of antihypertensive drugs was nevertheless associated with the decline in mortality from cardiovascular diseases, except for rheumatic heart disease, where the death rate fell mainly during 3 . the 1950s, that is, before the wide use of these drugs. The age-standardised death rate from hypertensive disease reached a peak in 1957 and then declined until 1976, similarly in both sexes $(-49 \%$ in males and $-58 \%$ in females). These data should $\frac{7}{0}$ nevertheless be treated with caution. Indeed, hypertension is often mentioned by physicians on $\mathcal{N}$ death certificates as an associated cause rather than the underlying one (Moriyama et al., 1971) and this alternative is influenced by diagnostic fashion (Clayton et al., 1977). 
The only figure published on the prevalence rate of oral contraceptive use in women in the reproductive age groups was $42 \%$ in 1972 (Rohner, 1974). This figure was obtained from a random sample of the population of a district comprising 3109 Swiss women aged 20 to 49 , of whom 414 were interviewed by self-administrated questionnaire with a response rate of only $50 \%$.Much lower prevalence rates $(16 \%$ in Swiss and $8 \%$ in Italian and Spanish women) were obtained by personal interviews with 396 women aged 15 to 44 in our study on varicose veins among an unselected female population of low socioeconomic level, working in department stores (Guberan et al., 1973). These limited data indicate nevertheless that the proportion of women using oral contraceptives is likely to be of the same order of magnitude as it is in other Western countries of Protestant background (Beral, 1976). If the trends in 1951 to 1962 in age-specific death rates for non-rheumatic heart disease and hypertension in women aged 25 to 54 are compared with the trends in 1962 to 1973 (Fig. 2), the introduction of oral contraceptives in the early 1960s does not seem to have had a significant influence. Since 1973, however, some increase in death rates occurred, but this was also the case in older female age groups and in males, and it was associated with economic factors discussed later.

Social risk factors must also be considered. Comparison of the data of the 1950 with those of the 1970 census (Federal Bureau of Statistics, 1951-77) shows that the percentage of professionally active women aged 15 to 64 increased from $39 \%$ to $50 \%$. During this period, the male to female ratio of death rates for non-rheumatic heart disease and hypertension increased, which is not in agreement with the hypothesis that the difference in coronary death rates between the sexes is related to the difference in occupational rates between men and women (Waldron, 1976).

Coronary mortality has also been found by various authors to be associated with urbanisation (Tyroler and Cassel, 1964; Moriyama et al., 1971). In Switzerland, however, the decline of death rates for non-rheumatic heart disease and hypertension was associated, between 1950 and 1970, with an increase in the percentage of the population living in urban centres of more than 100000 inhabitants $(24 \%$ to $35 \%)$ and a fall in the population engaged in the agricultural sector ( $16 \%$ to $7 \%)$.

Finally, it must be emphasised that the decline in cardiovascular mortality was associated with the growth of economic prosperity. The gross national product per caput increased by $97 \%$ (at constant prices) between 1951 and 1974 (Federal Bureau of Statistics 1951-77), when it became the second highest in the world after Kuwait (United Nations,
1977). With the advent of the economic recession, however, it decreased by $8 \%$ between 1974 and 1976. This inversion of the trend in economic growth was associated with an inversion of the trend in mortality from non-rheumatic heart disease and hypertension, which increased sharply in males and slightly in females (Figs. 1 and 2).

\section{Conclusion}

As is often emphasised, only association but not causation can be inferred from observational studies. However, the downward trend in cardiovascular mortality during the last 25 years in Switzerland, especially in females, remains a challenge. This dramatic decline of more than $40 \%$, unequalled in the 13 other countries studied, occurred at a time when Swiss women smoked more cigarettes, ate more animal fats, started extensive use of oral contraceptives, and increasingly left the peace of their villages for the stress of big towns and the warmth of their homes for the hard competition of occupational life.

I thank Mr. V. B. Dang of the Statistics Department of the Canton of Geneva for his huge work of computation.

Reprints from Dr. E. Guberan, 23, rue Ferdinand-Hodler, 1207 Geneva, Switzerland.

\section{References}

Abelin, Th., and Wüthrich, P. (1976). Repräsentativerhebung über die Rauchgewohnheiten in der deutsch-, französisch- und romanischsprachigen Schweiz 1975. Sozial-und Praeventiv-medizin, 21, 17-23.

Beral, V. (1976). Cardiovascular disease mortality trends and oral contraceptive use in young women. Lancet, 2, 1047-1052.

Clayton, D. G., Taylor, D., and Shaper, A. G. (1977). Trends in heart disease in England and Wales 1950-1973. Health Trends, 9, $1-6$.

Escher, M. (1977). Entwicklung der Hypertoniemortalität und des Hypertensiva-Verbrauchs in der Schweiz. Springer: Berlin.

Federal Bureau of Statistics (1951-1977). Annuaire Statistique de la Suisse. Birkhäuser: Basle.

Federal Bureau of Statistics (1955-1977). Mouvement de la population en Suisse. FBS: Bern.

Guberan, E., Widmer, L. K., and Glaus, L. (1973). Causative factors of varicose veins: myths and facts. Vasa, 2, 115-120.

Le Meitour-Kaplan, A. (1975). Situational analysis: profile of women's smoking habits in continental western Europe. In Proceedings of the 3rd World Conference on Smoking and Health, New York, vol. 2, pp. 309-327. US Department of Health, Education and Welfare: Washington DC.

Lee, P. N. (1975). Tobacco consumption in various countries. Research Paper No. 6, fourth edition. Tobacco Research Council: London.

Moriyama, I. M., Krueger, D. E., and Stamler, J. (1971). Cardiovascular Diseases in the United States. Harvard University Press: Cambridge, Massachusetts.

Rohner, W. (1974). Stand und Kenntnisse der Geburtenregelung. Thesis: University of Zurich. 
Secrétariat des Paysans Suisses (1951-1977). Statistiques et évaluations concernant l'agriculture et l'alimentation. SPS: Brugg.

Segall, J. J. (1977). Is milk a coronary health hazard? British Journal of Preventive and Social Medicine, 31, 81-85.

Todd, G. F. (1975). Changes in smoking patterns in the United Kingdom. Occasional Paper No. 1 Tobacco Research Council: London.

Tyroler, H. A., and Cassel, J. (1964). Health consequences of culture change-II The effect of urbanisation on coronary heart mortality in rural residents. Journal of Chronic Diseases, 17, 167-177.

United Nations Association (1956, 1965). Demographic Yearbook. United Nations Association: New York.

United Nations Association (1977). Statistical Yearbook 1976. United Nations Association: New York.
Waldron, I. (1976). Why do women live longer than men? Journal of Human Stress, 2, 2-13.

Walker, W. J. (1977). Changing United States life-style and declining vascular mortality: cause or coincidence? New England Journal of Medicine, 297, 163-165.

World Health Organisation (1954-1964). Annual Epidemiological and Vital Statistics. WHO: Geneva.

World Health Organisation (1965-1977). World Health Statistics Annual. WHO: Geneva.

World Health Organisation (1948). International Classification of Diseases, 6th revision. WHO: Geneva.

World Health Organisation (1957). International Classification of Diseases, 7th revision. WHO: Geneva.

World Health Organisation (1967). International Classification of Diseases, 8th revision. WHO: Geneva. 